\title{
World Disclosure and Normativity: The Social Imaginary as the Space of Argument
}

\section{Meili Steele}

\section{Introduction: Brandom and Taylor on World Disclosure and the Exchange of Reasons}

In a recent debate on language and rationality, Charles Taylor and Robert Brandom agree on many of the holistic assumptions of hermeneutics - what Brandom calls "Gadamerian platitudes"- but differ on the relationship of world disclosure to conceptual understanding and the exchanges of reasons. ${ }^{1}$ Brandom insists that we "draw a bright line between conceptual understanding and other kinds of symbolic disclosedness." In this view, "broadly symbolic [dimensions of language] in Cassirer's sense, are not conceptual in the narrow propositional sense that I render in terms of inference and reasons." "3e clarifies this by drawing on Wittgenstein's well-known analogy of language as a city: "Language for [Wittgenstein] is all suburbs, merging imperceptibly into the surrounding and supporting countryside of nonlinguistic practices, and having no downtown.... I think

1. Brandom uses the phrase to summarize some general assumptions that he wants to endorse: "the relativization of meaning to context in a very broad sense, the model of dialogue, meaning pluralism, the open-endedness and mutability of semantic perspectives" (Robert Brandom, Tales of the Mighty Dead [Cambridge, MA: Harvard UP, 2002], pp. 93-94). He adds: "But earning the entitlement to the commitments those platitudes express requires real work" (ibid., p. 94). Brandom differs in many important ways from Gadamer. See Cristina Lafont, "Meaning and Interpretation: Can Brandomian Scorekeepers Be Gadamerian Hermeneuts?" Philosophy Compass 2 (2007): 1-13.

2. Robert Brandom, "Reply to Taylor's 'Language Not Mysterious,"' Reading Brandom: On Making it Explicit, ed. Bernhard Weiss and Jeremy Wanderer (New York: Routledge, 2010), p. 303. "World Disclosure" is a translation of Heidegger's various terms "Erschlossenheit," "Lichtung," and "Ereignis."

3. Brandom, "Reply to Taylor's 'Language Not Mysterious,"” p. 302. 
language does have a downtown and that is the practice of giving and asking for reasons." ${ }^{4}$ The practice of giving and asking for reasons swings free not only of symbolic uses but of particular forms of life.

Taylor, on the other hand, does not think we can isolate reason giving from disclosure in this way, "I remain convinced that the articulative [disclosive] cannot be peeled off from the public giving of and asking for reasons." Any exchange over "the factual state of things" can only make sense if we set them "in the context of our ability to operate through the whole range of symbolic forms." Hence, "there are certain matters which can't be properly explored without recourse to the disclosive dimension. There couldn't be an intelligent discussion of the beauty of landscape which didn't either deploy or draw on our familiarity with, say, certain paintings. There couldn't be a discussion of Christian piety which didn't draw on, say, the music of Bach, or certain hymns, or Chartres Cathedral or an evocative life of Saint Francis." 7 For Taylor, there is a continuum between pure assertion-e.g., "Soup's on!"-where something is asserted but nothing is disclosed, and pure disclosure-e.g., Chopin's Fantaisie-Impromptu in C Sharp Minor, which "articulates a certain as yet indefinable longing.... A human possibility is articulated and disclosed here, but nothing is asserted." " Taylor gives artistic disclosure a privileged access to the distinctiveness of a form of life at the same time that he makes this disclosure ineffable. ${ }^{9}$

4. Brandom, "Reply to Taylor's 'Language Not Mysterious,"” p. 301. The reference here is to Wittgenstein's Philosophical Investigations, 4th ed. (Malden, MA: Blackwell, 2009), p. 11: "Our language can be seen as an ancient city: a maze of little streets and squares, of old and new house, and of houses with additions from various periods; and this surrounded by a multitude of new boroughs with straight regular streets and uniform houses."

5. Charles Taylor, "Language Not Mysterious," in Reading Brandom, p. 43.

6. Ibid., p. 34.

7. Ibid., p. 35 .

8. Ibid.

9. Taylor follows the German hermeneutic tradition here. Gadamer also gives art privileged disclosive access to our being in the world in a way that exempts art from normative claims: "Prior to all conceptual scientific knowledge, the way in which we look upon the world, and upon our whole being-in-the-world, takes shape in art" (Hans-Georg Gadamer, "Philosophy and Poetry," in The Relevance of the Beautiful and Other Essays, ed. Robert Bernasconi [Cambridge: Cambridge UP, 1986], p. 134). Gadamer opposes poetry and philosophy to everyday language: "Poetry and philosophy are both set off from the exchange of language as it takes place in practical activity and in science" (ibid., p. 133). Wolf Lepenies notes that "the antithesis of literature and poetry has been maintained in 
Although Brandon and Taylor share a holistic critique of the Kantian understanding of the concept, according to which the institution of conceptual norms is separate from their application, they develop different kinds of holism. ${ }^{10}$ For Brandom, the key is Hegelian reconstruction: "[T] he rationality of the current decision, its justifiability as a correct application of a concept, is secured by rationally reconstructing the tradition of its applications according to a certain model-by offering a selective, cumulative, expressively progressive genealogy of it. At each stage in its development, it is insofar as one takes the tradition to be rational, by a Whiggish rewriting of its history, that one makes the tradition be and have been rational... This is reason's march through history. In this way, as Hegel puts it, contingency is given necessity." "In his book on Hegel, Taylor states his opposition to this reconstructive logic of transparent concepts, insisting that "the clarity of our most explicit conceptual formulations repose on a background of which we are not fully aware." 12 Brandom concludes that Taylor is not a rationalist. ${ }^{13}$

While I agree with Taylor's claim for the importance of world disclosure, he makes a move that is all too typical of both defenders and critics of world disclosure by defining disclosure against everyday speech and normativity. In lumping together various aesthetic works and ignoring the disclosive power of everyday language, he fails to address the normative

all its severity only in Germany, where it has been exacerbated through an asociality of poetical production in principle, that even sees its chief task as being the 'refutation of the social"' (Wolf Lepenies, Between Literature and Science: The Rise of Sociology [Cambridge: Cambridge UP, 1988], p. 12).

10. As Brandom says, Kant offers "a two-phase story, according to which one sort of activity institutes conceptual norms, and then another sort of activity applies those concepts. First, a reflective judgment (somehow) makes or finds the determinate rule that articulates [a] concept. Then, and only then, can that concept be applied in the determinate judgments and maxims that are the ultimate subject of the first two Critiques" (Robert B. Brandom, "Some Pragmatist Themes in Hegel's Idealism: Negotiation and Administration in Hegel's Account of the Structure and Content of Conceptual Norms," European Journal of Philosophy 7 (1999): 166. Brandom's Hegel rejects this: "Our normative concepts are not instituted at the contractual level and then applied on the basis of the constitutive contract. They are instituted in the process of mutual recognition in which individuals hold one another responsible and implicitly impute to others the authority to keep normative track of one another's attitudes. This process does not need the social contract to get going or to get along" (ibid.).

11. Brandom, Tales of the Mighty Dead, p. 14.

12. Charles Taylor, Hegel (Cambridge: Cambridge UP, 1975), p. 467.

13. Brandom, "Reply to Taylor's 'Language Not Mysterious,"” p. 302. 
claims of disclosive writing that could answer disclosure's critics. ${ }^{14}$ Moreover, by giving poets and novelists blanket insight, he ignores the ways that literature can often be misleading, repulsive, or just stupid. ${ }^{15}$ Disclosive writing does not just reveal existing backgrounds; it can make normative arguments for the revision of social imaginaries.

This essay will not try to defend the normative relevance of all forms of disclosure to public debate, but it will show the disclosive and normative power of everyday speech and the argumentative relevance of literary modes of writing. My purpose is to show, through selected examples, how the notion of world disclosure can improve our understanding of normativity and enrich the kinds of normative arguments that can be made.

My exposition falls into three parts. In the first section, I look at the transcendental arguments that subtend claims to world disclosure and distinguish prereflective from reflective disclosure. In the second, I develop the idea of prereflective disclosure and show how there can be productive debate at this level, drawing on Taylor's conception of "social imaginaries" and on Talal Asad's Foucauldian critique of Taylor. In the third section, I will discuss reflective disclosure as a discrete normative speech act, by looking at the argumentative and disclosive power of ordinary prose in Susan Glaspell's short story “A Jury of Her Peers.” It offers a way of understanding normative reasoning that is not present in Brandom or Taylor. Moreover, this work addresses the dynamics of disclosure and power, something that is missing from most defenders of disclosure. ${ }^{16}$ From this example, I will generalize about world disclosure, argument, and normativity.

14. Cristina Lafont says: "Our world disclosure seems unrevisable from within and inaccessible from without" (Cristina Lafont, "World-Disclosure and Critique: Did Habermas Succeed in Thinking with Heidegger and against Heidegger?" Telos 145 [Winter 2008]: 170). Habermas says: "To the degree that the poetic, world-disclosing function of language gains primacy and structuring force, language escapes the structural constraints and communicative functions of everyday life" (Jürgen Habermas, Philosophical Discourse of Modernity, trans. Frederick Lawrence [Cambridge, MA: MIT Press], p. 204). Kristin Gjesdal says that Gadamer espouses "an aestheticizing model of understanding" that "prevents him from developing an adequate notion of normative issues in hermeneutics" (Kristin Gjesdal, Gadamer and the Legacy of German Idealism [Cambridge: Cambridge UP, 2009], p. 3).

15. Thomas Dixon's white supremacist novel The Clansmen, which served as the basis for D. W. Griffith's Birth of a Nation, would be an example of disclosive claims that are morally and politically repulsive.

16. This point has been raised against Gadamer, Taylor, and, most recently, Kompridis. See Amy Allen, "The Power of Disclosure," Philosophy and Social Criticism 37 (2011): 1025-31. 


\section{Prereflective and Reflective Disclosure}

A key feature that differentiates Taylor, Gadamer, and Heidegger from Brandom is the notion of "thrownness" (Geworfenheit) that Heidegger famously proposes in Being and Time. In this view, the subject should be understood as Dasein, thrown into the practices that can never be fully thematized and objectified. ${ }^{17}$ The worldhood into which we are thrownlanguages, social imaginaries, and practices-means that our thoughts, actions, and sentences do not spring from spontaneous, autonomous sources and for which we are entirely responsible. Utterances and actions depend on background that is logically prior to choice and reflection. In $A$ Secular Age, Taylor writes: "We are in fact all acting, thinking and feeling out of backgrounds and frameworks which we do not fully understand. To ascribe total personal responsibility to us for these is to want to leap out of the human condition." 18 Brandom, on the other hand, addresses the question of background by denying any idea of "thrownness." Background, for him, is a matter of choosing a context rather than something that makes choice possible: "The conceptual content of a claim can in principle be specified only against the background of some such set of commitments. The interpreter has considerable choice in selecting such a context or inferential perspective. But once such a point of view has been selected... then it is not at all up to the ascriber what the significance of the claims in question is in the chosen context. The context is, if you like, made; but then the inferential significance of a text in the context is found." 19

Because of their different understandings of our being in language, Brandom and Taylor have different views about how reasoning takes place. For Taylor, the task of reason is not achieved by parsing entailments and inferences but by seeking "to articulate a framework..., to try to spell out what is it that we presuppose when we make a judgment that a certain form

17. Martin Heidegger, Basic Problems of Phenomenology, trans. Alfred Hofstadter (Bloomington: Indiana UP, 1982), p. 297.

18. Charles Taylor, A Secular Age (Cambridge, MA: Harvard UP, 2007), p. 387. He makes the same point in Sources of the Self (Cambridge, MA: Harvard UP, 1989). We do not choose to commit to evaluative frameworks; rather, evaluative frameworks are logically prior to choice and reflection: "The point of view from which we might constate that all orders are equally arbitrary, in particular that moral views are equally so, is just not available to us humans. It is a form of self-delusion to think that we do not speak from a moral orientation which we take to be right. That's a condition of being a functioning self, not a metaphysical view we can put on or off" (p. 99).

19. Brandom, Tales of the Mighty Dead, p. 105. 
of life is truly worthwhile, or place our dignity in a certain achievement." ${ }^{20}$ These are the conditions of intentionality, and they are precisely "the background understanding surrounding any conviction that we ought not act in this or that way that procedural theory cannot articulate." ${ }^{21}$

We can get a grasp of what Taylor is after here by drawing on Nikolas Kompridis's distinction between prereflective and reflective world disclosure. Prereflective disclosure "refers to the disclosure of an already interpreted, symbolically structured world; the world, that is, within which we always already find ourselves." ${ }^{22}$ Reflective disclosure - and here I modify Kompridis's definition-is the intervention in the prereflective practices and structures of meaning by an utterance, work of art, etc. The agency of individual imagination expresses itself through and against the social imaginaries in which it finds itself.

Reflective disclosure reworks the languages and structures used to make sense of ourselves and the world, and these interventions can take the form of normative arguments, as we will see. Individual texts do not simply reveal what cannot be said in ordinary language about the current world, nor are they synecdoches for an era. There are many ways that texts make normative arguments.

Prereflective disclosure is the articulation of our passive relationship to structures of intelligibility, and Taylor's Modern Social Imaginaries illustrates this idea well. Here he discusses the public sphere, popular sovereignty, and other shared deep structuring features of Western modernity, and he does so without references to singular works of art, as he did in the Brandom debate, where reflective disclosure was at issue. Here the

20. Taylor, Sources of the Self, p. 26.

21. Ibid., p. 87; Charles Taylor, Philosophical Arguments (Cambridge, MA: Harvard UP, 1997), pp. 14-15.

22. Nikolas Kompridis makes this important distinction: "World disclosure refers, with deliberate ambiguity, to a process which actually occurs at two different levels. At one level, it refers to the disclosure of an already interpreted, symbolically structured world; the world, that is, within which we always already find ourselves. At another level, it refers as much to the disclosure of new horizons of meaning as to the disclosure of previously hidden or unthematized dimensions of meaning" (Nikolas Kompridis, "On World Disclosure, Heidegger, Habermas, and Dewey," Thesis Eleven [1994]: 37). Kompridis sensitive work rightly defends the cognitive status of world disclosure; however, he too separates normative argument from literary genres: "What does distinguish the world-disclosing activity of philosophy from that of literature is that it takes place in, is made possible by a different medium - the medium of argument, rather than the medium of fiction or appearance. In each case, the medium is distinctive of that practice" (Nikolas Kompridis, Critique and Disclosure [Cambridge, MA: MIT Press, 2006], p. 179). 
language of articulation is a socio-historical language of social imaginaries. For Taylor, giving genealogies of these background structures that we take for granted is relevant to the arguments of practical reason.

It is important to note that what Taylor is calling "background" is the onto-historical dimension of a community that has been developed in different ways by many thinkers who are dissatisfied with the narrow focus on normative reason giving that occupies liberal and deliberative theories. They often use the opposition "the political and politics," in which "the political" designates an onto-historical space that is occluded by liberalism. Claude Lefort's articulation has been perhaps the most influential, for he says that investigating the political means examining how the form of society gives the facts of political science "a meaning in the social space... as a space of intelligibility articulated in accordance with a specific mode of distinguishing between the real and the imaginary, the true and the false." 23 The political helps thematize what is blocked out by a political science that focuses only on factual elements of society and by a philosophy of language that begins by separating reason giving from forms of life. ${ }^{24}$

\section{Social Imaginaries and the Negotiation of Disciplines}

In Modern Social Imaginaries and A Secular Age, Taylor uses the term "social imaginaries" to talk about the ontological background of Western modernity, citing as his immediate source Benedict Anderson's Imagined Communities. Anderson's work explains the transition from dynastic regimes to modern nations, not by focusing on the self-conscious political ideologies of the eighteenth century and their ways of understanding the nation-e.g., social contract theories for the derivation of norms - but by drawing on the problematic of social imaginaries in order to reconstruct

23. Claude Lefort, Democracy and Political Theory, trans. David Macey (Minneapolis: Univ. of Minnesota Press, 1988), p. 11.

24. For a recent treatment of Lefort and literature, see Martin Plot, "Tlön as Political Form: Democracy and Totalitarianism in Borges and Lefort," Constellations 19 (2012): 463-79. Chantal Mouffe says that "politics refers to the 'ontic' level while 'the political' has to do with the 'ontological' one. This means that the ontic has to do with the manifold practices of conventional politics, while the ontological concerns the very way in which society is" (Chantal Mouffe, The Political [New York: Routledge, 2005], p. 8). Marcel Gauchet, for instance, says that the political is a way of discussing "the totality of human societies," while "politics" is simply "the face that the political takes on in our society" (Marcel Gauchet, La Condition politique [Paris: Gallimard, 2005], p. 532). I will look at Talal Asad's critique at this level in a moment. 
the organizing identities and cultural systems of medieval life, the dynasty/ kingdom, and the sacred text. It was through and against these that modern nationalism emerged. ${ }^{25}$ Anderson's approach to the history of culture is to speak of "imagined communities"- that is, communities held together not by mere spatial connection, such as a village, but by common forms and styles of imagination for understanding identity, time, etc., forms that were shaped by new media of the eighteenth century, the modern novel, and the newspaper. The effect of objectification of time in literature, Anderson argues, is to make it normal for us to envisage unconnected events as occurring simultaneously in the same story space. The reader is made into an omniscient observer, able to hold these independently unfolding trains of events together. Author and reader are like God watching them in a common space, an organizing form of consciousness that brings people together. ${ }^{26}$

However, Taylor cannot appropriate Anderson's work directly, for its third-person sociological approach to texts is external, offering explanatory structures, not a phenomenological laying out of the imaginaries into which participants are "thrown" and through which they think and act. ${ }^{27}$ Hence, Taylor develops the social imaginary as a kind of background in the Heideggerian sense so that it is brought into a problematic of Dasein's "thrownness": "The social imaginary is not a set of ideas; rather, it is what enables, through making sense of, the practices of a society.... [Thus,] the notion of moral order goes beyond some proposed schedule of norms that ought to govern our mutual relations and/or political life.... The image of order carries a definition not only of what is right, but of the context in which it makes sense to strive for and hope to realize the right." ${ }^{28}$ The development of such an understanding of moral means "is the coming to be of certain social forms," forms that the problematic of the imaginary can articulate. ${ }^{29}$ What Taylor wants from sociologists such as Anderson,

25. Benedict Anderson, Imagined Communities: Reflections on the Origin and Spread of Nationalism (London: Verso, 1991), p. 12. Taylor cites Anderson in Modern Social Imaginaries and A Secular Age.

26. Taylor's interest in the novel is shaped by Anderson's and Ian Watt's formalist approaches. All Taylor wants from the novel is the new shape of time and the elevation of ordinary life, not new ways of thinking.

27. Taylor never articulates his differences from Anderson, Heidegger, or Gadamer. He simply imports their ideas and develops them in his own way.

28. Charles Taylor, Modern Social Imaginaries (Durham, NC: Duke UP, 2004), pp. 2, 8-9.

29. Ibid., p. 2. Imaginaries are the middle level of articulation, between the "explicit doctrines about society, the divine or the cosmos." The second is "the symbolic," which 
and from historians such as François Furet and Edmund Morgan, is a language that can articulate how societies were reshaped and how they thematized this reshaping through time..$^{30}$ This fine-grained analysis, such as Morgan's on popular sovereignty, is missing from hermeneutic characterizations, such as Gadamer's tradition, which largely ignore modern political institutions.

Social imaginaries work in an analogous way to Heidegger's distinction between ontological and ontic interpretation. The ontic interpretation looks at whether an issue within the world of a particular culture: for example, whether forbidding the wearing of headscarves by flight attendants violates the First Amendment in the United States or the doctrine of laïcité in France. Ontological interpretation, on the other hand, investigates how things show up at all - in this case, whether the very idea of secularity is present.

We can see the relationship of the ontological background (the political) to politics in Taylor's work by looking quickly at $A$ Secular Age. At the beginning of $A$ Secular Age, he distinguishes three kinds of secularism. The concerns of philosophers of public reason are placed in "Secularity 1," which focuses on the retreat of religion from the common institutions and practices, "most obviously, but not only, the state." 31 This is the normative, political secularism of public reason that addresses such controversies as the wearing of headscarves to school or the display of religious symbols on state grounds. ${ }^{32}$ A second sense of secularity refers to the decline of religious belief and practice-people no longer going to church, synagogue, or mosque, for instance. This sociological approach is often called "secularization." 33 The third and most important sense of secularity for

is found in art and ritual and close to what historians call "mentalités," and the third is "embodied understanding," or "habitus" (Charles Taylor, "Two Theories of Modernity," Public Culture 11 [1999]: 167).

30. Edmund S. Morgan, Inventing the People: The Rise of Popular Sovereignty in England and America (New York: Norton, 1989); François Furet, Penser la révolution française (Paris: Gallimard, 1978).

31. Taylor, A Secular Age, p. 1.

32. The French idea of "laïcité" is a set of principles and practices that establish the relationship of religion and the state. See Catherine Kintzler, Qu'est-ce que la laïcité? (Paris: Vrin, 2007). For the American debates, see Kent Greenawalt, Religion and the Constitution, 2 vols. (Princeton, NJ: Princeton UP, 2009).

33. For a concise treatment of some of the issues in comparative secularization, see José Casanova, "Rethinking Secularization: A Global Comparative Perspective," The Hedgehog Review (Spring/Summer 2006): 7-22. Subtraction stories can also work by 
Taylor concerns the shift in "the conditions of belief," since this sense gives a place to the ontological history he finds important. On this view, the "shift to secularity consists of a move from a society where belief in God is unchallenged and unproblematic to one in which it is understood to be one option among others, and frequently not the easiest to embrace." In other words, Taylor wants to examine the shift "which takes us from a society in which it was virtually impossible not to believe in God, to one in which faith, even for the staunchest believers, is one possibility among others." 35

Taylor's claim for Secularity 3 is not simply that this is a better description of contemporary society's understanding of religion and secularity. His claim is philosophical. Although we may have much to learn from researchers in Secularity 1 and 2, they have left out the worldhood of the world. Sociologists may focus on gathering statistics about church or synagogue attendance as evidence of secularization, while political philosophers may assert the uncontroversial "fact of pluralism" in order to focus on the construction of norms of mutual accommodation. ${ }^{36}$ But before these facts or norms can make sense, they require a background that lets them appear for us as phenomena. Of course, people can bring different ideas and attitudes to a secularity, but "what they do not bring into the negotiations is the set of ideas and norms constitutive of [secularity itself]. These must be the common property of society before there can be any question of [debate]. Hence, they are not subjective meanings, the property of one or some individual, but rather intersubjective meanings, which are constitutive of the social matrix in which individuals find themselves and act." ${ }^{37}$ Hence, Taylor's question is: what are the background assumptions,

speaking of modernity's differentiation - e.g., the economy moves from the household to its own sphere or "health care" moves from the church to other institutions - but are missing the complex ways societies is changing.

34. Taylor, A Secular Age, p. 3.

35. Ibid.

36. John Rawls says, "Political liberalism that, for political purposes, a plurality of reasonable yet incompatible comprehensive doctrines is the normal result of the exercise of human reason within the framework of the free institutions of the constitutional regime" (John Rawls, Political Liberalism [New York: Columbia UP, 1993], p. xvi). Moreover, Rawls claims, history has already shown that this is possible, "History tells of a plurality of not unreasonable comprehensive doctrines" (ibid., p. 140).

37. Charles Taylor, Philosophical Papers, vol. 2 (Cambridge: Cambridge UP, 1985), p. 36. I have substituted "secularity" for the "negotiation" in this well-known passage from Taylor's work since he is making the same point with secularity. 
practices, languages, etc., that make the contemporary experience of the secular and the religious possible, for believers, agnostics, and atheists? We stand in a normed world of social imaginaries that cannot be set aside to get clear about particular normative concepts.

Taylor does a genealogy of Western secularity that gives a new account of how our current background assumptions emerged, drawing out new historical richness and complexity that becomes available and normatively relevant through this problematic. We cannot just toss in a vague, schematic historical tale about how secularity emerged from the wars of religion and modern science in order to focus on the principles of public reason. ${ }^{38}$ Rather, "our sense of where we are is crucially defined in part by a story of how we got there.... And just because we describe where we are in relating a journey, we can misdescribe it grievously by misidentifying the itinerary. That is what the subtraction accounts of modernity have in fact done. To get straight where we are, we have to go back and tell the story properly." 39 To get oriented to the world and our place in it requires more than abstract principles, such as "the separation of church and state," for they block out the massive background that shapes reasoning. Normativity cannot swing free from contestable historical accounts of how our self-understandings came about because it is woven from specific social imaginaries.

Taylor's articulations interrogate this space, seeking "to transfer what has sunk to the level of an organizing principle for present practices and hence beyond examination into a view for which there can be reasons either for or against." ${ }^{\prime 40}$ In this way, Taylor wants to begin reasoning by

38. Rawls gives his famous capsule summary of the background to liberalism in the introduction to Political Liberalism: "Thus the historical of origin of political liberalism... is the Reformation and its aftermath, with the long controversies over religious toleration in the sixteenth and seventeenth centuries" (Rawls, Political Liberalism, p. xxiv). See Jan-Werner Muller, "Rawls, Historian: Remarks on Political Liberalism's 'Historicism,"' Revue Internationale de Philosophie 60 (2006): 327-39.

39. Taylor, A Secular Age, p. 29.

40. Charles Taylor, "Philosophy and Its History," in Philosophy in History, ed. Richard Rorty et al. (Cambridge: Cambridge UP, 1984), p. 28. Taylor is not always clear about the relationship of philosophical concepts to imaginaries. When he speaks of the "modern moral order," for instance, he suggests that the moral order is first a theory that trickles into imaginaries: "In the course of expansion, it [moral order] moved from being a theory, animating the discourse of a few experts, to becoming integral to our social imaginary, that is, the way our contemporaries imagine the societies they inhabit and sustain" (Taylor, Modern Social Imaginaries, p. 4). Here he suggests that the imaginaries can be the point 
reopening the assumptions of modernity and displaying the complex, conflicted historical inheritance that lies behind current usage. This means learning to think historically about how we came to be who we are today by "undo[ing] forgetting."."

Taylor's account moves between third-person narration from a neoDurkheimian angle that looks at large-scale shifts in the structure of imaginaries to first-person renderings of the participants' own language, what he calls particular "spins" on this background. The external account of meaning and social practices alternates with a phenomenology of different kinds of belief and nonbelief, showing different takes on what it feels like to live in a secular age: "I want to talk about belief and unbelief, not as rival theories, that is, ways that people account for existence or morality, whether by God or by something in nature, or whatever. Rather, what I want to do is focus attention on the different kinds of lived experience involved in understanding your life in one way or the other, on what it's like to live as a believer or unbeliever." ${ }^{2}$

The purpose of Taylor's articulations is not simply to improve our understanding of the past but to enrich our normative debates of the present by broadening the space of argument. By providing a genealogy of Western secularity as complex knot of historical processes peculiar to Western Christianity, rather than a principle that needs to be applied, Taylor makes any use of this concept more contextually dependent and vulnerable than the reductive constructions of normative philosophy and sociology. The widespread interdisciplinary debate over his work is a testament not just to the quality of the work but to the enriched landscape of normative reasoning that his work solicits. Taylor gives us more to argue with and about. ${ }^{43}$

\section{Critique of Taylor's Ontological History}

It has been a standard criticism of Taylor's Sources of the Self and A Secular Age that these ontological histories ignore conflict, otherness, oppression,

of initiation for philosophical concepts. My focus is on the imaginary as a place where argument can take place.

41. Taylor, "Philosophy and Its History," p. 21.

42. Taylor, A Secular Age, pp. 4-5.

43. Taylor, A Secular Age, p. 29. Taylor himself is not entirely clear on how he understands the normative and deliberative importance of Secularity 3 -i.e., the consequences for Secularity 1 of bringing Secularity 3 into the process. See his recent work on Secularity 2, Secularism and Freedom of Conscience, with Jocelyn Maclure (Cambridge, MA: Harvard UP, 2011). I discuss some of these issues in "Secularism and Public Reason." 
and colonialism. ${ }^{44}$ I will discuss briefly Talal Asad's critique of Taylor's work because he makes it at the ontological, prereflective level in his Formations of the Secular, showing how background becomes an important site for debate. I will then move to my critique of his understanding of narrative and imaginaries in reflective disclosure. I will bring the two points together with my example in the next section.

Asad announces at the beginning of his work that he will distinguish the historico-ontological enterprise of studying secularity from the narrowly focused debates on principle and policy: "It is a major premise of this study that 'the secular' is conceptually prior to the political doctrine of 'secularism,' that over time a variety of concepts, practices and sensibilities have come together to form 'the secular.' In chapters that follow I begin with a partial genealogy of that concept, an effort aimed at questioning its self-evident character while assuring at the same time that it nevertheless marks something real... Genealogy is not intended here as a substitute for social history ('real history' as many would put it) but as a way of working back from our present to the contingencies that have come together to give us our certainties." ${ }^{45}$ If he is like Taylor in his concern with modernity's misdescriptions of itself through time, he is less focused on the articulation of the conditions of possibility than he is on the power of these misdescriptions to shape the world. Asad makes a disclosive counterargument: "The important question is therefore not to determine why

44. See Saba Mahmood, "Can Secularism Be Otherwise?" Varieties of Secularism (Cambridge, MA: Harvard UP, 2010); and Peter van der Veer, "Smash Temples, Burn Books: Comparing Secularist Projects in India and China," in Rethinking Secularism, ed. Craig Calhoun et al. (Oxford: Oxford UP, 2011). In his reply to Quentin Skinner's criticism that he avoids political conflicts over women's roles in the family in Sources of the Self, Taylor says: "In speaking of family, what I am attributing to 'us' is rather a whole lineage. The point is not to overlook battles over sexual reactions but to point out how much both sides actually share" (Charles Taylor, "Comments and Replies," Inquiry 34 [1991]: 238). This reply shows the way Taylor's ontological approach to background can elide crucial shifts in the imaginary.

45. Talal Asad, Formations of the Secular (Stanford, CA: Stanford UP, 2003), p. 16. Asad insists on large-scale genealogical disclosure: "What is distinctive in modern anthropology is the comparison of embedded concepts (representations) between societies differently located in time or space. The important thing in this comparative analysis is not their origin (Western or non-Western), but the forms of life that articulate them, the powers they release or disable. Secularism - like religion - is such a concept" (ibid., p. 17). Asad directs his critique at Taylor's "Modes of Secularism," in Secularism and Its Critics, ed. Rajeev Bhargava (Oxford: Oxford UP, 1998), which is oriented toward Secularism 1, state policy, in which Taylor advocates a version of Rawls's "overlapping consensus." 
the idea of 'modernity' (or 'the West') is a misdescription, but why it has become hegemonic as a political goal, what practical consequences follow from that hegemony, and what social conditions maintain it." ${ }^{\prime 46}$ Asad shows how secularism continues its Christian origins, working itself into a grammar of modernity, including human rights (see chapter 4 of Formations of the Secular). ${ }^{47}$

He explores exactly what Taylor's Heideggerian holism ignores: the relationship of secularism to domination. While Taylor thinks of the ontological as the unrecognized condition of possibility, Asad looks at the way this ontological sharing is a forced imposition on different positions. "Secularism," for Asad, "is not simply an intellectual answer to a question about enduring social peace and toleration. It is an enactment by which a political medium (representation of citizenship) redefines and transcends particular and differentiating practices of the self that are articulated though class, gender, and religion.." Asad's comparative critique puts pressure on Taylor's account not just to acknowledge aspects of the history that it has denied or left out; rather, Asad is disclosing a deep ontological layering of the social imaginaries and of concepts that go unnoticed by Taylor's construal of ontological history. Answering Asad's critique would require the inclusion of ignored encounters with others as well as a revision of Taylor's description of the structures of the imaginaries and the concepts of normativity that are bound up with them. In order to understand what a revision would look like, we need to examine Taylor's conception of narrative and see how it keeps him from examining the arguments of stories.

\section{Reflective Disclosure or Reasoning through the Social Imaginary}

Social imaginaries, as Taylor describes them, provide the space for a new conception of disclosure and practical reasoning, but, as we have seen, he does not follow through on how reflective disclosure can argue. Taylor gives a large place to narrative, especially in A Secular Age, but he never speaks of narratives, fictional or nonfictional, as forms of reflection by individuals and groups in political arguments over the shapes of modern

46. Asad, Formations of the Secular, p. 13, emphasis in original. Asad's project is to examine "changes in the grammar of concepts" (ibid., p. 25). Asad, like Taylor, draws on the notion of "habitus" to talk about embodied capacities (ibid., p. 95).

47. In "The Construction of Religion as an Anthropological Category," in Genealogies of Religion (Baltimore: Johns Hopkins UP, 1993), Asad examines how Clifford Geertz's notion of religion as a universal category embeds Christian assumptions within it.

48. Asad, Formations of the Secular, p. 5. 
imaginaries. When he speaks of literary or historical texts, he takes a formalist view of the novel and narrative borrowed from Anderson and Ian Watt or drops a casual footnote to MacIntyre or Ricoeur, while ignoring the dynamic struggle of imaginaries.

In his debate with Brandom, he moves from the nondisclosive "Soup's on!" to the untranslatable notes of Chopin, ignoring some obvious examples of disclosive argument in literature's engagement with social imaginaries. In Proust's $A$ la recherche du temps perdu, the text offers a dramatic critique of realism and its assumptions through its mode of presentatione.g., parody of the Goncourt brothers - and through its philosophical statements In La Nausée, Sartre argues with Proustian assumptions about time, language, and the phenomenology of experience through its narrative technique as much as through its propositions. ${ }^{49}$ These texts focus on the structures of intelligibility both in and outside literary practice. However, such arguments are also present in works that do not make explicit philosophical statements. Jonathan Swift argues with the scientific, literary, and political culture of his day in Gulliver's Travels through satire, parody, exaggeration, and other means. Henry James, who avoids commentary on his narratives, implicitly attacks, through his depiction of consciousness, normativity, and language, the understanding of language, mind, and normativity presented by Flaubert's texts. ${ }^{50}$ To address this topic fully, I would have to work through a theory of the novel and its challenge to understandings of the aesthetic, which would pull my essay off the topic of normativity. Nonetheless, it is worth mentioning the work of Mikhail Bakhtin, who emphasizes the need for a prosaics instead of a poetics to address the distinctively modern genre, the novel. Criticizing traditional poetics for its focus on the formal or stylistic unity of a work, Bakhtin understands the novel as engaging and orchestrating all the languages

49. In his essay on The Sound and Fury, Sartre says, "A novelistic technique always refers back to the metaphysics of the novelist" (Jean-Paul Sartre, Situations [Paris: Gallimard, 1947], 1:71). Taylor's inattention to disclosive narrative arguments also keeps him from exploring spiritual options, as several commentators have noted. Peter E. Gordon says, "What I am trying to suggest is that Taylor's textured history of background should have awakened him to the (possibly distressing) thought that there are many modes of the sacred and many kinds of wonder and that the Christian religion is merely one historical deposit" (Peter E. Gordon, "The Place of the Sacred in the Absence of God," Journal of the History of Ideas 69 [2008]: 672).

50. On James, see my essay "The Philosophical Importance of Henry James's Late Style," The Henry James Review 35 (2014): 209-17, where I contrast my conception of normativity in James with those of Martha Nussbaum and Robert Pippin. 
of the imaginary-literary, political, sociological, philosophical, etc. ${ }^{51}$ Bakhtin provides modes of thematizing, interrogating, and revising the languages of the modern social imaginaries in ways that are missing from philosophies of world disclosure and social science. ${ }^{52}$ This does not mean that literary or other disclosive works are necessarily perspicuous or that they make good arguments. My point is to talk about disclosure in terms of prose writing, in and outside literature, so as to enrich the ways that disclosive language can contribute to practical deliberation. What follows is a focused philosophical example of the kind of argument I mean.

Susan Glaspell's short story "A Jury of Her Peers" offers a phenomenology of interpretation in a straightforward everyday language that opens the boundaries of art and everyday speech and shows how narratives can make normative arguments. ${ }^{53}$ The tale begins when Mrs. Hale is called from her work in the kitchen to join her husband, Mr. Peters (the sheriff), and his wife. Mrs. Hale, the center of focalization for the third-person narrative, learns that Mr. Wright, the husband of an old friend, has been killed. The sheriff suspects Mrs. Hale's friend Minnie has killed her husband. The group proceeds to the Wrights' home, where it splits up. The men go out to the barn to look for evidence that can establish a motive for Minnie, while the women wait in the kitchen. While sitting there, they encounter the "text" of Minnie's life-the dirty towels, the mishandled stitching on her quilt, the act of violence of which she is suspected, and so on. That is, the dominant tradition that the women bring to Minnie's house, a tradition that they share with their husbands, forms preunderstandings that do not help them reconstitute the self-understanding of the text. The men have called Minnie "mad," and the women at this point can articulate no other reading, even though they sense that more is at stake here for them.

51. See Mikhail Bakhtin, The Dialogic Imagination, trans. Caryl Emerson and Michael Holquist (Austin: Univ. of Texas Press, 1981). Bakhtin's philosophy of language and the novel is far too rich and complex for me to develop here.

52. Bakhtin asks us to see that "what is realized in the novel is the process of coming to know one's own language as it is perceived in someone else's language, coming to known one's own conceptual horizon in someone else's conceptual horizon (Bakhtin, Dialogic Imagination, p. 365). The novel is not concerned with capturing the speech of an era but with what he calls "the image of language," which "reveals not only the reality of a given language but also, as it were its potential, its ideal limits" (ibid., p. 356).

53. Susan Glaspell, "A Jury of Her Peers," in Best Short Stories of 1917 (Boston: Small, Maynard, 1918). 
Slowly the women start to put together an explanation of the strangeness of Minnie's text - the systematic psychological torture to which her husband subjected her, a torture that culminated in the strangulation of Minnie's double, her pet bird. The process of coming to this explanation forces them to transform the understandings of their own lives and indeed the gendered imaginaries of the time. Minnie's text asks them disturbing questions, not just the other way around. To understand this text means that they can no longer remain who they are. They discover that Minnie's husband was not just "a cruel man" but also a typical one and that Minnie's response differs only in degree, not in kind, from the ones they have felt but repressed. It is important that Mr. Wright commits no actionable offense. He merely brings into relief the norms that are already there and that inform the actions within many marriages. The story's off-stage narrator shows their complex interaction with the text-sometimes it grabs them and sometimes they push it away - that is rarely made explicit in their consciousness or in dialogue. The women are not exchanging claims in discursive dialogue in which they use the constructed political concepts to unmask ideology. ${ }^{54}$ They are experiencing a rupture in the very medium that constitutes them-i.e., Glaspell is arguing through the imaginary in displaying this rupture. The context of their reading - their moments of isolation interrupted by their husbands' condescending remarks about the triviality of women's occupations - helps foster their transformative reading. The women come to understand that the values and textures of their own lives are neither read nor recognized by their husbands and that the forces that drove Minnie mad operate around and within them as well. The women discover the narrow social space in which they have been channeled to live and the anger that they have been socialized to ignore. They begin to understand that, in Catherine MacKinnon's words, "dominant narratives are not called stories. They called are reality.",55

Ambivalent about this knowledge that their reading is bringing about, they alternately leap at it and hide from it. The boundaries of their selves

54. Edward Said's Culture and Imperialism (New York: Knopf, 1993) and Seyla Benhabib's The Claims of Culture (Princeton, NJ: Princeton UP, 2002) exemplify this way of thinking about normativity. They objectify and unmask the languages of texts as unreliable ethical or political guides, while drawing their normative authority from a neo-Kantian universalism that can be separated from its damaged historical instantiations.

55. Catherine MacKinnon, "Law's Stories as Reality and Politics," in Law's Stories: Narrative and Rhetoric in the Law, ed. Peter Brooks and Paul Gewirtz (New Haven, CT: Yale UP, 1996), p. 235. 
have been unraveled as Minnie's text speaks not only to them but for them: "It was as if something within her not herself had spoken, and it found in Mrs. Peters something that she did not know as herself." ${ }^{156}$ Interpretation in this story is dramatized as an event, not an act. When Mrs. Peters discovers the strangled bird, she does not just solve a detective's riddle; she reworks the fabric of her memory and identity. As she recalls and revises the story of what a boy with a hatchet had done to her cat many years ago, she gets back the rage of the past moment: "'If they hadn't held me back, I would have..." Minnie's text forces them to see themselves and their husbands in a way that requires a new language that gives distinctiveness and worth to lives and that goes unread by the dominant culture. The women do not "empathize" with Minnie by learning the particulars of her life. Nor do they learn to apply a principle of nondomination or antidiscrimination. Instead, Minnie's text forces them to change who they are and how they understand their lives and marriages. ${ }^{57}$

Unlike Minnie, they are able to create a way of speaking that unites them with each other and separates them from the men. They have formed a powerful normative language that gives them reasons to do something they never could have imagined before they arrived at the Wrights' house. They have created a "new space of reasons," to use Wilfrid Sellars's famous phrase. ${ }^{58}$

Their interpretations open a new, hitherto unthinkable space of action: they choose to hide the bird (conceal evidence), betray their husbands, and break the law. There is nothing ineffable about this disclosure, but the reasons of the argument do not appear in terms of the principles of public reason, such justice and equality. Certainly, such notions inform the

56. Glaspell, “A Jury of Her Peers,” p. 272.

57. I am thus opposed to Nussbaum's conception of literature as providing access to an alternative life, a subject to subject conception in which literary texts offer a kind of specificity and emotional richness missing from both universalizing normative theory and the social sciences. Hence, it is not surprising that she does not see her view as incompatible with that of sensitive Kantians: "My own preferred version of the ethical stance derives from Aristotle, but everything I say here could be accommodated by a Kantianism modified so as to give the emotions a carefully demarcated cognitive role" (Martha Nussbaum, Poetic Justice [Boston: Beacon Press, 1995], p. xvi). Normativity is located safely in principles and the argumentative work through the imaginary is ignored.

58. In Empiricism and the Philosophy of Mind (Cambridge, MA: Harvard UP, 1997), Sellars writes that "in characterizing an episode or a state as that of knowing, we are not giving an empirical description of that episode or state; we are placing it in the logical space of reasons, of justifying and being able to justify what one says" (76). 
background, but these notions are woven into the textures of their shared imaginaries, and their revisions of their existing understandings occur at the level of the imaginary rather than explicit naming. The third-person narrator articulates the new space of understanding that emerges for them without ever reducing it to a conceptual label. This understanding of public reason shows how the languages of the social imaginary of identity are bound up with normativity. These "identities" are large-scale formations that involve the articulation of individualism, gender, autonomy, the public sphere, etc., as well as fine-grained distinctions that shape this particular American social space at this particular time.

Thus, in answer to Brandom's charge - and those of other critics of world disclosure - that world disclosure does not offer reasons and to Taylor's failure to connect disclosure to normativity, I would say that this story is Susan Glaspell's disclosive, argumentative reasoning. ${ }^{59}$ It offers a complex account of the discovery of violence embedded in one configuration of norms and meanings, of one configuration of reason giving. Rather than understanding reasoning as the application of the same principles, we must take up the complex claims about the normativity of shared imaginaries. How does one go from not seeing domination to seeing it? Not through the application of a constructed principle, but by normative articulations that open up new ways of being in the world. Instead of reasoning by constructing a normative principle on which citizens "ought" to agree and then applying it, we reason by tacking between accounts of our ontological background and the interpretive normative intervention that we make. ${ }^{60}$

59. This conception of narrative is directly at odds with Ricoeur's, which keeps novelists out of the argument business, limiting them only to emplotment. "Historians are not simply narrators: they give reasons.... Poets also create plots that are held together by causal skeletons. But these... are not the subject of a process of argumentation. Poets restrict themselves to producing the story and explaining by narrating.... [Poets] produce, [historians] argue" (Paul Ricoeur, Time and Narrative, trans. Kathleen Blaney [Chicago: Univ. of Chicago Press, 1984], 1:186. By looking at narrative as the formal emplotment of the heterogeneous, Ricoeur blocks out the way in which emplotment is always a reemployment of the narrative and symbolic shapes that the subject inevitably inhabits. I have developed this critique in Hiding from History: Politics and Public Imagination (Ithaca, NY: Cornell UP, 2005), pp. 48-54.

60. It is important to distinguish this conclusion from what is often called the "pragmatist solution," in which all we have are applications of norms. As Frank Michelman puts it, "Pragmatism thus attacks our grip on the idea of the priority of norms to decisionson the idea, that is, that prior agreement on the contents of the applicable norms is what grounds or determines whatever agreements we may find we have about the resolutions of particular social disputes.... Pragmatism leaves it unclear what the normal norms - the 
In my view, what is prior to the decision is not the content of a principle derived from a constructivist idealization, but instead the historico-ontological background and the significant interventions that have been made or blocked out. That is why debate always has to be about what is subtending our self-understandings and not just what is in front of us.

Glaspell's text is not an isolated example of such reasoning. Ralph Ellison's fictional and nonfictional works argue with America's racial imaginaries by holding up racial structuring for the reader and then working through these structures. ${ }^{61}$ Understanding social imaginaries as the space of argument is not limited to literature, of course, and we find many examples in political philosophy and the real world, from the Arab Spring to contemporary photography. ${ }^{62}$ Once normativity is understood through the imaginaries, the shape of normative argument must be flexible enough to acknowledge and address the claims that reflective disclosures make about the background that has shaped us and the normative future that remains to be articulated.

nominal principles of justice for example — can possibly ever be or have been but traces of their applications to date and reflections." Frank Michelman "The Problem of Constitutional Interpretive Disagreement," in Habermas and Pragmatism, ed. Mitchell Aboulafia et al. [New York: Routledge, 2002], p. 114.

61. Ellison understood novels as arguments: "All novels of a given historical moment form an argument over the nature of reality and are, to an extent, criticisms of each other" (Ralph Ellison, Collected Essays of Ralph Ellison [New York: Modern Library, 1995], p. 165). I develop this reading of Ellison in "The Social Imaginary as a Problematic for Human Rights," in Theoretical Perspectives on Human Rights and Literature (New York: Routledge, 2011).

62. See, for instance, Chiara Bottici and Benoît Challand, eds., The Politics of Imagination (New York: Birkbeck Law Press, 2011), which includes an essay by Challand on imaginaries and imagination in Islamism and by Susan Buck-Morss on photography. 